\title{
Asset markets, financial intermediaries and growth in emerging markets and beyond
}

\author{
Ansgar Belke ${ }^{1,2} \cdot$ George Chortareas ${ }^{3}$
}

(C) Springer-Verlag GmbH Germany, part of Springer Nature 2017

The European Economics and Finance Society (EEFS) hosted its Fourteenth Annual Conference from June 11 to 14, 2015 in Brussels and its Fifteenth Annual Conference from June 16 to 19, 2016, in Amsterdam - both in collaboration with the journal "International Economics and Economic Policy". The conferences addressed topics within the spectrum of international economics, trade theory, international macroeconomics and international finance. The focus was strongly on deriving policy conclusions to lessen the probability of further crises and to identify issues and questions for further research.

A peer-reviewed selection of the papers presented at both conferences is presented in this issue. These contributions can be grouped around five main topics. Five papers fall into the category of "exchange rates and monetary policy in developed and emerging economies". The topics "public debt, monetary policy and economic growth", "banking", "housing markets" and "trade policy" are each covered by two contributions.

\section{Exchange rates and monetary policy in developed and emerging economies}

Our compilation starts with the paper by Sophia Latsos and Gunther Schnabl which comes up with an analysis of the net foreign asset positions and appreciation expectations on the Swiss Franc and the Japanese Yen. The authors show that that currencies of countries with persistent current account surpluses and high foreign-currency denominated assets, such as the Swiss franc and the Japanese yen, are under persistent appreciation pressure, particularly when the centres of the world monetary system

\section{Ansgar Belke}

1 University of Duisburg-Essen, D-45117 Essen, Germany

2 Centre for European Policy Studies, Brussels, Belgium

3 King's College, London, UK 
follow expansionary monetary policies. This limits the choice of exchange rate regime. Given flexible exchange rates, a negative risk premium on the domestic interest rate can emerge. Their empirical estimations, however, provide mixed evidence for a negative impact of net foreign asset positions and exchange rate uncertainty on interest rates of international creditor countries at the periphery of the world monetary system.

Valentyna Ozimkovska studies the relationship between real financial market exchange rate volatility (RFER) and US cross-border equity flows. She finds strong evidence that causality goes from real financial market exchange rate volatility to equity flows. In particular, real financial market exchange rate volatility negatively influences purchases of foreign equity. This finding is in line with the portfolio optimization theory. The impact of real financial market exchange rate volatility on sales of foreign equity also turns out to be negative. This result is consistent with the behavioral finance approach, which suggests that investors are reluctant to realize losses of their portfolios and therefore investors decrease sales of assets when the riskiness of these assets increases. The impact of the real financial market exchange rate on net purchases of foreign equity is positive. It follows from these results that sales of foreign equity decrease more strongly than purchases of foreign equity when the riskiness of foreign assets increases.

In his contribution Joseph P. Joyce investigates the role of external balance sheets as countercyclical buffers. The external balance sheets of many emerging market countries are distinguished by their holdings of assets primarily in the form of foreign debt and foreign exchange reserves, while their liabilities are predominantly equity, either foreign direct investment or portfolio equity. Taking this as a starting point, the paper investigates the claim that this composition served as a buffer for the emerging markets during the global financial crisis of 2008-09. The author uses data from a sample of 67 emerging market and advanced economies, and several indicators of the crisis are utilized: GDP growth rates in 2008-09, the occurrence of bank crises and the use of IMF credit. The empirical results show that those countries that issued FDI liabilities had higher growth rates, fewer bank crises and were less likely to borrow from the IMF. Countries with debt liabilities, on the other hand, had more bank crises and were more likely to use IMF credit. Joyce concludes that the "long debt, short equity" (hold debt assets, issue equity liabilities) strategy of emerging markets did mitigate the effects of the global financial crisis.

In the next contribution, Ansgar Belke and Christian Fahrholz dwell on emerging and small open economies, unconventional monetary policy and exchange rates. Since the outset of the Great Recession, in 2007, central banks of major-currency economies have adopted non-standard monetary policies. The authors examine whether and to what extent these measures pose a challenge to central banking in emerging and small open economies. In particular, they assess how global liquidity spillovers caused by major central banks affect the economic dynamics of emerging and small open economies. In this respect, economies which are close to, or even at, the periphery of major-currency economies are particularly prone to "unbalanced" real exchange rate dynamics. In the short run, corresponding level and volatility effects in key relative prices may endanger financial stability in the recipient country. The long-term effects include a metamorphosis of the anchoring of private-sector inflation expectations into a perilous tightrope act in central banking of these economies.

Stephanos Papadamou, Eleftherios Spyromitros and Nikolaos A. Kyriazis consider the effects of Quantitative Easing (QE) on commercial bank liability and government 
yields in the United Kingdom. During the recent financial crisis, the Bank of England has taken quantitative easing measures by buying public as well as private assets in order to strengthen the economy via liquidity injections. This paper investigates the dynamic relationship between unconventional policy measures reflected in central bank's assets, and government versus commercial bank liability curves in a nonlinear framework. By adopting a threshold cointegration methodology the authors provide evidence against linearity in gilt and commercial banks' yield responses to asset purchase facility (APF) activity with policy rate being near the zero lower bound (ZLB). By estimating a momentum-TART model, evidence for a uni-directional long run causality from the Bank of England's assets to both curves is present.

\section{Public debt, monetary policy and economic growth}

In the paper "Public Debt and Economic Growth - Economic Systems Matter Markus Ahlborn and Rainer Schweickert refer to the stylised fact that most studies on the relationship between public debt and economic growth implicitly assume homogeneous debt effects across their samples. In accordance with recent literature the authors challenge this view and state that there likely is a great deal of cross-country heterogeneity in that relationship. However, other than scholars assuming that all countries are different, their prior is that clusters of countries differ. In fact, they are able to identify three country clusters with distinct economic systems: liberal (Anglo Saxon), continental (Core EU members) and Nordic (Scandinavian) countries. The authors argue that different degrees of fiscal uncertainty at comparable levels of public debt between those economic systems constitute a major source of heterogeneity in the debtgrowth relationship. Their empirical evidence supports this assumption. Continental countries face more growth reducing public debt effects than especially Liberal countries. There, public debt apparently exerts neutral or even positive growth effects, while for Nordic countries a non-linear relationship is discovered, with negative debt effects kicking in at public debt values of around $60 \%$ of GDP.

The next contribution by Raphael Fischer and Gunther Schnabl deals with regional heterogeneity, the rise of public debt and monetary policy in Japan. It starts from the observation that both Japan and parts of the European Monetary Union have experienced booms and busts in stock and real estate markets, which have been followed by a lasting crisis. The paper analyzes the role of a high degree of regional heterogeneity for public debt and monetary policy in the context of crisis. The authors show that the attempts to maintain regional cohesion via a regional transfer mechanism in Japan has contributed to the unprecedented rise in public debt and persistent monetary expansion. Their econometric estimations show that in Japan regional redistribution of funds has ensured homogeneous living conditions across Japanese regions pre- and post-crisis. The side condition is monetary expansion. They conclude that a similar effect could emerge in Europe, if the crisis persists.

\section{Banking}

Tommaso Gabrieli, Keith Pilbeam and Bingxi Shi then deal consider the impact of shadow banking on the implementation of Chinese monetary policy. Their paper empirically 
analyzes the relationship between the shadow banking system and implementation of monetary policy in China. Using the VECM methodology, the authors show that an increase in the size of shadow banking raises the independence of bank lending from the policies of the People's Bank of China. They find that shadow banking works in an asymmetric fashion in that it amplifies increases in the money supply but weakens the effects of restrictive interest rate-based monetary policy decisions.

In the next paper, Ulrich Haskamp looks at at a specific kind of spillover of banking regulation. This paper analyzes the German bank levy which was implemented from 2011 until 2014. The author examines not only if banks shift the cost of the levy to their customers' lending rates, but also whether there are spillovers to their local competitors. The German savings and cooperative banks are a natural setting to study such effects, as they only operate within well-defined regions, allowing the author to identify their local competitors. Additionally, only some of them are subject to the levy due to a tax allowance. The author finds that a bank that has to pay the bank levy raises its lending rate by about 0.14 percentage points. Secondly, he examines whether the increased lending rates of paying banks spill over to their local competitors. He finds this indirect effect to be about one third of the size. Lastly, adverse effects of the levy on paying banks' loan supply growth are absorbed by their competitors to a certain extent.

\section{Housing markets}

Theodoros Panagiotidis'and Eleni Kyriazakou's contribution uses a nonlinear pair-wise approach to assess the long-run convergence of UK regional house prices for twelve regions. The time period spans from 1983:1 to 2012:4. Linear, nonlinear and asymmetric unit root tests are considered for assessing the stationarity of all possible pairs. The test statistic for convergence is based on the percentage of unit root test rejections across all regional house price differentials. The percent of the pairs that reject the null increase from $6 \%$ in the linear ADF case to $53 \%$ for the nonlinear unit root. Probit analysis reveals that house price differentials in the South are more likely to be stationary and as a result tend to converge more compared to the North.

Tommaso Gabrieli, Keith Pilbeam and Tianyu Wang estimate of bubble dynamics in the Chinese real estate market based on a state-space model. The authors take as their starting point that the Chinese real estate market has been through an exceptional blooming phase in recent years and the central government acted through a series of policies in order to stabilize it. The authors analyze the existence of a bubble in the Chinese real estate market and estimate its driving factors with a State-Space model. The model considers macroeconomic and real estate time series variables as inputs and employs a Kalman filtering method to obtain an estimated demand and supply of real estate. By doing this, the model obtains an estimated equilibrium real estate price justified by fundamentals. The authors then measure the derivation ratio between actual and estimated equilibrium real estate prices in order to test for existence of a bubble. They also estimate the driving factors impacting on the deviation ratio by further regression analysis. They find robust evidence for the existence of a bubble, especially after 2009. They also gain empirical evidence that loose monetary policy and informal banking are important factors affecting prices and that government policies do not seem to have achieved the desired stabilizing effect. 


\section{Trade policy}

The paper by Frederick Stender, "Mercosur in Gravity: An Accounting Approach to Analyze its Trade Effects" aims at unveiling the roots of integration-induced trade effects for the Mercosur en bloc. For this purpose, its methodology combines traditional dummy variable approaches with continuous variable approaches to identify trade creation and trade diversion effects in a gravity model framework. Conducting a straightforward accounting exercise on the integration-induced trade effects that are found for Mercosur en bloc, two central results emerge. Firstly, with sectoral exceptions, the author generally identifies pure trade creating effects on the import side but also finds trade diversion with associate countries when refining extra-bloc country status. Secondly, while extra-bloc import growth seems to be driven predominantly by non-tariff determinants, trade creation in pooled sectoral imports for the largest fraction stems from variation in tariff treatment of trading partners.

In a final paper Susanne Gaede and Dirk Heine assess the unilateral removal of implicit subsidies for maritime fuels. Among academics and policymakers, it is generally agreed that implicit tax subsidies for maritime fuels (which are currently granted around the world) are inefficient, but that their abolishment requires a unanimous international agreement. Such an agreement is deemed indispensable because any unilateral action would be impossible due to massive tax competition in this industry, competitiveness effects and the legal limits on regulating an industry operating mostly in international waters, thus outside of any state's jurisdiction. However, an international agreement to solve these problems has proven impossible to reach, thus resulting in the conservation of the status quo. To break this deadlock, the authors propose a mechanism whereby a small coalition of countries, to start with, can abolish these implicit tax subsidies even in the absence of an international agreement. The effects of acting without a world-wide agreement are analysed from an economic perspective, taking into account the current legal framework. The coalition considered in this article focuses on EU member states, although the mechanism is applicable more widely.

The European Economics and Finance Society (EEFS) fourteenth and fifteenth Annual Conferences in Brussels and Amsterdam provided the opportunity for participants to gain new insights into some highly topical issues. We want to thank Paul Welfens for giving us a special issue of the International Economics and Economic Policy. We would also like to thank the "Wissenschaftsförderung der SparkassenFinanzgruppe e.V." for generous funding. We are also heavily indebted to the referees of the papers included in this special issue, their reports resulted in substantial and significant improvements that were highly appreciated by the authors of papers accepted in this special issue. 